\title{
Hubungan Dukungan Sosial dengan Kesepian pada Narapidana Dewasa Awal Lajang
}

\author{
Grace Ayunita Batara ${ }^{1}$, Sri Aryanti Kristianingsih ${ }^{2}$ \\ ${ }^{1,2}$ Fakultas Psikologi, Universitas Kristen Satya Wacana, Salatiga, Indonesia \\ Correspondence email: graceayunita097@gmail.com
}

\begin{abstract}
Abstrak. Penelitian ini bertujuan untuk mengetahui hubungan antara dukungan sosial dengan kesepian pada narapidana dewasa awal lajang. Subjek dalam penelitian ini narapidana dewasa awal lajang yang berjumlah 30 orang berusia 18-40 tahun. Data dianalisis menggunakan korelasi product moment dari Karl Pearson. Cara penghitungannya dibantu dengan menggunakan program SPSS. Hasil penelitian ini menunjukkan bahwa ada hubungan negatif antara dukungan sosial dengan kesepian $(\mathrm{r}=-$ $0,357, \mathrm{p}=0,026)$. Besarnya hubungan variabel dukungan sosial terhadap kesepian adalah $12,8 \%$ sedangkan sisanya $87,2 \%$ dipengaruhi oleh variabel lain. Hal ini berarti, semakin tinggi dukungan sosial maka semakin rendah kesepian pada narapidana dewasa awal lajang, begitu pula sebaliknya semakin rendah dukungan sosial maka semakin tinggi kesepian narapidana dewasa awal lajang. Peneliti selanjutnya diharapkan untuk dapat mengembangkan faktor-faktor lain yang memengaruhi variabel kesepian pada narapidana seperti jenis kelamin dan status sosial ekonomi.
\end{abstract}

Kata Kunci: Dukungan sosial; kesepian; narapida dewasa awal lajang

Abstract. This study aims to determine the relationship between social support and loneliness in early single adult prisoners. The subjects in this study was an early single adult convict of 30 people 18-40 years of age. Data were analyzed using correlation product moment from Karl Pearson. The calculation method is assisted by using the SPSS program. The results of this study indicate that there is a negative relationship between social support and loneliness $(r=-0.357, p=0.026)$. The magnitude of the influence of social support variables on loneliness is $12.8 \%$ while the remaining $87.2 \%$ is influenced by other variables. This means, the higher the social support, the lower the loneliness of early adult inmates, and vice versa, the lower the social support, the higher the loneliness of early adult prisoners to be single. Researchers are expected to be able to develop other factors that influence the variable loneliness inmates such as gender and socioeconomic status.

Keywords: Social support; loneliness; early adult inmates are single

\section{PENDAHULUAN}

Indonesia adalah negara yang berdasarkan hukum sebagaimana diatur dalam pasal 1 ayat (3) UUD 1945 dan sebagai negara hukum, maka untuk menjalankan suatu negara dan perlindungan hak asasi manusia harus berdasarkan hukum. Dalam hal menentukan suatu perbuatan yang dilarang atau tindak pidana dalam suatu peraturan perundang-undangan digunakan kebijakan hukum pidana (Utami dan Wijaya, 2017).

Setiap warga negara yang melanggar hukum akan dikenakan perlakuan hukum yang sesuai dengan apa yang telah diperbuatnya. Lembaga Pemasyarakatan mempunyai fungsi sebagai tempat pembinaan dan pemidanaan atas tindak kriminal narapidana yang telah ditetapkan masa hukuman dan pengurungannya oleh hakim atau mahkamah Panjaitan dan Simorangkir (dalam Nur dan Shanti, 2011).

Kehidupan narapidana di Lembaga Permasyarakatan (Lapas) dan Rumah Tahanan (rutan) merupakan bentuk dari konsekuensi hukuman atas perilaku yang melanggar hukum (Estu, 2017). Di dalam UU No. 12/1995 tentang Pemasyarakatan pengertian narapidana adalah terpidana yang hilang kemerdekaan di lembaga pemasyarakatan. Terpidana adalah seseorang yang dipidana berdasarkan putusan pengadilan yang telah memperoleh kekuatan hukum tetap. Menyandang status sebagai narapidana dan menjalani hukuman dengan rentang waktu yang cukup lama seringkali menimbulkan permasalahan psikologis bagi para narapidana (Ekasari \& Susanti, 2009).

Narapidana selama berada di rutan menghadapi berbagai masalah psikologis maupun masalah dalam kehidupan sehari-harinya seperti diabaikan oleh keluarga, kehilangan dukungan, kehilangan kebebasan karena sedang menjalani masa tahanan, kehilangan hak untuk menentukan sesuatu sendiri, serta kehilangan rasa aman (Meilina, 2013). Salah satu dampak psikologis yang dialami para narapidana selama menjalani masa hukuman di lembaga pemasyarakatan adalah kesepian. Rutan merupakan suatu tempat yang tertutup dan jauh dari perhatian masyarakat dan keluarganya. Perubahan seseorang yang masuk Rumah Tahanan dan pasti terjadi adalah keharusan para narapidana untuk meninggalkan keluarga dan teman-temannya. Hal ini dapat menyebabkan reaksi-reaksi tersendiri dari para narapidana, salah satunya adalah menyebabkan munculnya kesepian karena perpisahan dengan orangorang yang dicintai seperti teman, anak, istri dan anggota keluarga lainnya Cooke, dkk (dalam Nur \& Shanti , 2011). 
Narapidana yang masih terikat hubungan pernikahan, merasakan kesepian yang berbeda dengan narapidana yang tidak menikah. Narapidana yang tidak menikah cenderung memiliki tingkat kesepian yang tinggi dibandingkan dengan narapidana yang menikah, karena tidak adanya orang terdekat untuk berbagi pikiran dan pengalaman mengenai permasalahan yang menimpa dirinya. Kurang adanya dukungan dari orang-orang terdekat itulah yang menyebabkan seorang narapidana yang tidak menikah akan mengalami kesepian (Perlman \& Peplau, dalam Hayati, 2009). Dewasa awal yang masih lajang juga mengalami kesepian dimana masa dewasa awal merupakan proses untuk membentuk suatu keluarga, mendapatkan pekerjaan, dan memilih teman. Apabila individu belum dapat menjalin hubungan interpersonal dengan orang lain, maka ia akan mengalami perasaan terisolasi. Oleh karena itu, dewasa muda lajang yang belum memiliki pasangan dianggap sudah memasuki usia kritis dan memiliki risiko mengalami kesepian (Sari \& Listiyandini, 2015).

Russell (1996) mendefinisikan kesepian sebagai hubungan sosial yang tidak sesuai dari apa yang diinginkan, termasuk perasaan gelisah, tertekan, dan persepsi kurangnya hubungan sosial pada diri seseorang. Ada 3 aspek yang disusun oleh Russell (1996) yaitu trait loneliness, adanya pola yang lebih stabil dari perasaan kesepian yang terkadang berubah dalam situasi tertentu, atau individu yang mengalami kesepian karena disebabkan kepribadian mereka, kepribadian yang dimaksud adalah seseorang yang memiliki kepercayaan yang kurang terhadap orang asing. Social desirability loneliness yaitu terjadinya kesepian karena individu tidak mendapatkan kehidupan sosial yang diinginkan pada kehidupan di lingkungannya. Depression loneliness yaitu terjadinya kesepian karena terganggunya perasaan seseorang seperti perasaan sedih, murung, tidak bersemangat, merasa tidak berharga dan berpusat pada kegagalan yang dialami individu.

Hasil wawancara yang telah dilakukan peneliti untuk data awal pada narapidana Rutan Salatiga pada bulan Januari 2019, menunjukkan bahwa dari narapidana lajang yang diwawancarai mengalami kesepian. Faktor utamanya adalah berpisah dengan keluarga, adanya perubahan lingkungan yang mereka rasakan, serta terbatasnya akses dan fasilitas. Berikut ini kutipan hasil wawancara peneliti yang menunjukkan adanya kesepian yang dialami oleh narapidana:

"Selama saya berada di sini dan melihat temanteman saya yang dikunjungi oleh pasangan dan juga anak-anaknya membuat saya merasa bahwa di usia saya saat ini seharusnya saya seperti teman-teman saya yang lain yang sudah membangun sebuah keluarga. Sehingga ketika saya mengalami masalah seperti ini saya tidak merasa kesepian karena memiliki keluarga yang dapat mendukung saya dan juga menjadi penyemangat untuk saya".(E, 14 Januari 2019).

Ada beberapa faktor yang menyebabkan timbulnya kesepian menurut Gottileb (1998) yaitu: (1) Situasi, berpisah dengan keluarga, teman lama merupakan sebab utama kesepian dan menimbulkan suatu kebutuhan akan orang lain. (2) Kepercayaan, pikiran-pikiran yang menyatakan diri sendiri tidak berguna dan tidak disukai oleh orang lain akan memperburuk kesepian. (3) Kepribadian, adanya korelasi antara kesepian dengan sejumlah karakteristik personal, yang meliputi rendahnya harga diri, rasa malu yang besar, merasa diasingkan, dan kepercayaan bahwa dunia bukanlah tempat yang menyenangkan. Dari berbagai faktor kesepian yang telah dijelaskan sebelumnya penyebab kesepian antara lain dipengaruhi oleh kurangnya dukungan sosial dari keluarga dan masyarakat.

Fessman dan Lester (dalam Hayati, 2009) mengemukakan bahwa dukungan sosial merupakan prediktor bagi munculnya kesepian. Kesepian merupakan gejala yang dapat terjadi pada setiap individu, dimana kondisi kesepian itu sendiri memiliki kadar yang berbeda pada masing-masing individu, meskipun begitu secara khas hal tersebut dipengaruhi oleh kualitas dukungan sosial yang diterimanya. Narapidana yang memperoleh dukungan sosial keluarga yang kurang cenderung akan mengalami kesepian, sementara narapidana yang memperoleh dukungan sosial yang lebih baik tidak terlalu merasa kesepian. Hal ini juga menunjukkan akan pentingnya interaksi sosial di kalangan narapidana untuk mengatasi masalah kesepian.

Dukungan sosial sendiri dapat mengacu pada kenyamanan, kepedulian, penghargaan, atau bantuan yang diterima oleh seseorang dari orang lain atau kelompok (Sarafino, dalam Hasan \& Mulyadi, 2014). Dukungan sosial mungkin saja datang dari berbagai pihak, tetapi dukungan sosial yang amat bermakna dalam kaitannya dengan masalah kesepian adalah dukungan sosial yang bersumber dari mereka yang memiliki kedekatan emosional, seperti anggota keluarga dan kerabat dekat (Gusarna, 2004).

Keluarga dapat berperan sebagai pemberi dukungan sosial yang membantu individu ketika suatu masalah muncul (Videbeck, dalam Elita, dkk, 2015). Individu yang mengalami dukungan sosial terbatas maka peluang mengalami kesepian tinggi, sedangkan individu yang dukungan sosialnya baik maka tingkat mengalami kesepian rendah.

Ada 6 aspek yang disusun oleh Cutrona dan Russell (1987) untuk mengukur ketersediaan dukungan sosial yang diperoleh dari hubungan individu dengan orang lain, yaitu Guidance merupakan saran atau informasi yang bertujuan untuk memcahkan masalah atau kesulitan yang dialami oleh individu tertentu. 
Reassurance of wort merupakan keyakinan seseorang di mana menjalin atau memiliki hubungannya yang bernilai dengan orang lain. Social integration merupakan proses dinamis dan berprinsip di mana semua anggota dalam suatu kelompok sosial berpartisipasi dalam mengungkapkan pendapat untuk mencapai dan mempertahankan hubungan sosial yang damai. Reliable alliance merupakan hubungan antara dua atau lebih individu baik dalam kelompok maupun tidak yang dianggap positif dan dapat diandalkan saat diperlukan bagi kedua belah pihak yang terlibat. Attachment merupakan suatu ikatan emosional yang mendalam yang menghubungkan satu orang ke orang lain. Opportunity of nurturance merupakan kesempatan yang dimiliki seseorang untuk dapat memberikan perhatian secara emosional maupun fisik kepada orang lain.

Dukungan sosial sangat dibutuhkan karena merupakan bentuk pertolongan yang dapat berupa materi, emosi dan informasi yang diberikan oleh orangorang yang memiliki arti seperti keluarga, sahabat, teman, saudara, rekan kerja ataupun atasan atau orang yang dicintai oleh individu yang bersangkutan, Maysithah (dalam Putri, 2018).

Beberapa peneliti yang melihat hubungan antara dukungan sosial dan kesepian diantaranya, Hayati (2009) dalam penelitiannya menunjukkan bahwa terdapat hubungan yang signifikan antara dukungan sosial dengan kesepian pada lansia. Hubungan ini bersifat negatif yang berarti bahwa semakin tinggi skor dukungan sosial subjek, maka semakin rendah skor kesepian subjek. Sejalan dengan penelitian Ikasi dkk, (2014) diperoleh bahwa lansia dengan tingkat kesepian (loneliness) yang rendah lebih banyak yaitu 42 responden $(56,0 \%)$ dibandingkan dengan tingkat kesepian (loneliness) yang tinggi. Hal ini disebakan semakin tinggi dukungan keluarga yang didapatkan lansia maka akan menurunkan resiko terjadinya kesepian dan stress ataupun masalah psikologis pada lansia. Penelitian Nur dan Shanti (2011) menunjukkan bahwa ada hubungan negatif yang sangat signifikan antara dukungan sosial keluarga dengan kesepian pada narapidana. Uji statistik menghasilkan nilai $\mathrm{t}=8,038$ dengan $\mathrm{p}=0,000(\mathrm{p}<0,01)$ yang menunjukkan adanya perbedaan kesepian yang sangat signifikan antara narapidana yang menikah dengan narapidana yang tidak menikah dimulai dari usia 21 tahun.

Dari penelitian sebelumnya dengan penelitian ini memiliki kesamaan variabel mengenai dukungan sosial dan kesepian. Tetapi perbedaan yang mendasar antara penelitian sebelumnya dan penelitian yang akan peneliti lakukan, yaitu perbedaan objek peneliti dan tempat penelitian. Objek penelitian sebelumnya pada lansia sedangkan pada penelitian ini fokus pada dewasa awal. Usia lanjut berbeda dengan dewasa awal karena memasuki usia lanjut cenderung akan menarik diri dari lingkungan masyarakat dan akan lebih sibuk dengan dirinya sendiri, hal tersebut menyebabkan adanya penurunan interaksi sosial yang menyebabkan mereka dapat menurunkan kualitas hidup mereka Santrock (dalam Putri, 2016). Sedangkan masa dewasa awal merupakan transisi dari masa remaja menuju dewasa, pada masa ini kepribadian seorang individu cenderung sudah stabil dan mampu menentukan pilihannya sendiri. Hurlock (1996) menyatakan bahwa pada masa dewasa awal memiliki tugas yang dipusatkan pada harapanharapan masyarakat seperti mendapat pekerjaan, memilih seorang teman hidup, belajar hidup dengan suami/istri dan membentuk suatu keluarga. Hal ini sesuai dengan pernyataan Santrock (2003), yaitu membina hubungan intim dengan lawan jenis merupakan tugas perkembangan yang spesifik bagi individu dewasa awal, jika tugas perkembangan tersebut tidak terpenuhi maka akan dapat menganggu keberhasilan tugas-tugas perkembangan pada masa selanjutnya. Adanya penurunan dalam hubungan yang dekat dapat menjadi alasan bagi seseorang untuk mengalami kesepian.

Selain itu, pada penelitian sebelumnya dengan penelitian ini objek penelitiannya pada narapidana, namun yang menjadi perbedaanya yaitu penelitian sebelumnya pada narapidana yang ditinjau dari status perkawinan sedangkan pada penelitian ini fokus pada narapidana dewasa awal yang masih lajang. Narapidana dewasa awal yang masih lajang berbeda dengan narapidana yang sudah menikah karena narapidana dewasa awal yang masih lajang merasa bahwa narapidana yang sudah menikah lebih sering dikunjungi oleh keluarga (suami/istri dan anak) sedangkan narapidana yang masih lajang jarang dikunjungi oleh keluarga (berdasarkan wawancara dengan narapidana dewasa awal lajang pada Januari, 2019). Hal ini didukung oleh Perlman dan Peplau (dalam Hayati, 2009) bahwa kesepian merupakan reaksi terhadap ketidakhadiran dari pasangan suami atau istri pada diri seseorang. Bruno (2000) menjelaskan bahwa kesepian adalah suatu keadaan mental dan emosional yang terutama dicirikan oleh adanya perasaan-perasaan terasing dan kurangnya hubungan yang bermakna dengan orang terdekatnya, seperti orang tua maupun pasangan. Begitu juga halnya dengan para narapidana, bahwa status perkawinannya akan memberikan makna tersendiri. Narapidana tidak akan merasa kesepian meskipun berada di dalam lapas karena merasa mendapat dukungan dari orang-orang yang dicintainya.

Berdasarkan uraian di atas, dukungan sosial dirasa perlu untuk dikaji lebih lanjut terkait fungsinya dengan perasaan kesepian pada narapidana dewasa awal yang belum menikah atau lajang. Oleh karena itu, peneliti tertarik untuk meneliti hubungan antara dukungan sosial dan kesepian pada narapidana dewasa awal lajang. 


\section{Hipotesis}

Berdasarkan latar belakang serta teori yang ada maka hipotesis dalam penelitian ini adalah adanya hubungan negatif antara dukungan sosial dengan kesepian pada narapidana dewasa awal lajang. Semakin tinggi dukungan sosial maka semakin rendah tingkat kesepian pada narapidana dewasa awal lajang, begitu pula sebaliknya semakin rendah dukungan sosial maka semakin tinggi tingkat kesepian pada narapidana dewasa awal lajang.

\section{METODE}

Pendekatan yang digunakan dalam penelitian ini adalah pendekatan kuantitatif. Adapun dalam penelitian ini peneliti menggunakan metode penelitian kuantitatif korelasional, yaitu penelitian yang meneliti tentang ada tidaknya hubungan antara variabel-variabel yang diteliti (Arikunto, 2010).

Variable terikat dalam penelitian ini adalah kesepian yang merupakan pengalaman menyedihkan yang terjadi ketika hubungan sosial seseorang tidak sesuai yang diinginkan, termasuk perasaan gelisah, tertekan, dan kurangnya hubungan sosial pada diri seseorang. Variabel bebas dalam penelitian ini adalah dukungan sosial suatu hubungan yang mengacu pada kenyamanan, kepedulian dengan segala bentuk dukungan, cinta, serta memberikan bantuan kepada individu yang mengalami tekanan.

Populasi dalam penelitian ini adalah narapidana dewasa awal lajang di Rumah Tahanan Negara Kelas IIB Salatiga yang berjumalah 30 narapidana. Teknik pengambilan sampel yang digunakan yaitu sampling jenuh.

Pengumpulan data dalam penelitian ini dilakukan dengan menggunakan dua skala yaitu, dukungan sosial dan kesepian. Skala Dukungan Sosial berdasarkan pada teori Cutrona dan Russell (1987) dan dimodifikasi oleh penulis berdasarkan konteks pada narapidana dewasa awal lajang yang berada di dalam Rutan, terdiri dari 24 aitem dengan kemungkinan empat pilihan jawaban yang terdiri dari Sangat Setuju (SS), Setuju (S), Tidak Setuju (TS), dan Sangat Tidak Setuju (STS). Skala Kesepian berdasarkan pada teori Russell (1996) yang dimodifikasi oleh penulis untuk narapidana dewasa awal lajang yang terdiri dari 20 aitem dengan kemungkinan empat pilihan jawaban yang terdiri dari tidak pernah, jarang, kadang, dan selalu.

Pada penelitian ini peneliti melakukan uji diskriminasi aitem, sebagai kriteria pemilihan aitem berdasarkan korelasi item total, Kriteria seleksi aitem berdasarkan batasan $r_{i x} \geq 0,25$, maka aitem yang memiliki daya beda dari $\mathrm{r}_{\mathrm{ix}} \leq 0,25$ menunjukkan aitem tersebut memiliki ukuran yang rendah sehingga perlu untuk dihilangkan atau gugur (Azwar, 2013).

Hasil perhitungan dari uji diskriminasi aitem skala dukungan sosial yang terdiri dari 24 aitem dan diujikan kepada 30 responden, menghasilkan 21 aitem yang diterima dan 3 aitem yang gugur dengan nilai koefisien sebesar 0,878. Hasil perhitungan dari uji diskriminasi aitem skala kesepian yang terdiri dari 20 aitem dan diujikan kepada 30 responden, menghasilkan 13 aitem yang diterima dan 7 aitem yang gugur dengan nilai koefisien sebesar 0,799 .

\section{HASIL DAN PEMBAHASAN Hasil}

Peneliti melakukan penelitian di Rumah Tahanan Negara Kelas IIB Salatiga dengan cara membagikan skala penelitian dukungan sosial dan kesepian kepada 30 narapidana dewasa awal lajang dengan usia 18-40 tahun (Hurlock, 1994).

Sampel pada penelitian ini adalah narapidan dewasa awal lajang di Rumah Tahanan Negara Klass IIB Salatiga.

Data sampel pada populasi dapat dilihat pada tabel berikut:

\section{Analisis Deskriptif}

Pada bagian ini akan ditampilkan gambaran kategorisasi dukungan sosial pada warga binaan Rumah Tahanan Salatiga. Dengan menentukan tinggi rendahnya variabel peneliti menggunakan empat kategori dengan perhitungan interval sebagai berikut:

Tabel 1: Kategorisasi Skala Dukungan Sosial

\begin{tabular}{llll}
\hline \multicolumn{1}{c}{ Kategori } & \multicolumn{1}{c}{ Interval } & \multicolumn{1}{c}{$\mathrm{N}$} & Persentase \\
\hline Sangat Tinggi & $68,25 \geq \mathrm{x}<84$ & 11 & $37 \%$ \\
Tinggi & $52,5 \geq \mathrm{x}<68,25$ & 16 & $53 \%$ \\
Rendah & $36,75 \geq \mathrm{x}<52,5$ & 13 & $10 \%$ \\
Sangat Rendah & $21 \geq \mathrm{x}<36,73$ & 0 & $0 \%$ \\
Total & & 30 & $100 \%$ \\
& & & \\
Max $=83$ & Min $=40$ & SD $=9,0452$ \\
\hline
\end{tabular}

Hasil yang diperoleh menunjukkan bahwa 11 narapidana memiliki dukungan sosial sangat tinggi (37\%), 16 narapidana memiliki dukungan sosial tinggi (53\%), 3 narapidana yang memiliki dukungan sosial rendah (10\%), dan tidak ada narapidana yang memiliki dukungan sosial sangat rendah $(0 \%)$.

Pada bagian ini akan ditampilkan gambaran kategorisasi kesepian pada warga binaan Rutan Salatiga. Dengan menentukan tinggi rendahnya variabel peneliti menggunakan empat kategori dengan perhitungan interval sebagai berikut:

Tabel 2. Kategori Skor Kesepian

\begin{tabular}{llll}
\hline \multicolumn{1}{c}{ Kategori } & \multicolumn{1}{c}{ Interval } & $\mathrm{N}$ & Persentase \\
\hline Sangat Tinggi & $42,25 \geq \mathrm{x}<52$ & 1 & $3 \%$ \\
Tinggi & $32,5 \geq \mathrm{x}<42,25$ & 2 & $7 \%$ \\
Rendah & $22,75 \geq \mathrm{x}<32,5$ & 18 & $60 \%$ \\
Sangat Rendah & $13 \geq \mathrm{x}<22,75$ & 9 & $30 \%$ \\
Total & & 30 & $100 \%$ \\
Max $=49$ & Min $=17$ & SD $=6,5544$ & \\
\hline
\end{tabular}


Hasil yang diperoleh menunjukkan bahwa 9 narapidana memiliki kesepian sangat rendah (30\%), 18 narapidana memiliki kesepian rendah $(60 \%), 2$ narapidana memiliki kesepian tinggi $(7 \%)$, dan 1 narapidana memiliki kesepian sangat tinggi (3\%).

\section{Analisis Data \\ Uji Asumsi \\ Uji Normalitas}

Tabel 3. Uji Normalitas

One-Sample Kolmogorov-Smirnov Test

\begin{tabular}{llll} 
& & X & Y \\
\hline N & & 30 & 30 \\
Normal Parameters $^{\mathrm{a}}$ & Mean & 65.33 & 26.93 \\
& Std. Deviation & 9.045 & 5.554 \\
Most Extreme & Absolute & .116 & .096
\end{tabular}

$\begin{array}{lll}\text { Positive } & .065 & .096 \\ \text { Negative } & -.116 & -.065 \\ & .635 & .525 \\ & .815 & .945\end{array}$

Kolmogorov-

Smirnov Z

Asymp. Sig. (2-

tailed)

a. Test distribution is

Normal.

Berdasarkan uji normalitas yang telah dilakukan, diketahui bahwa sebaran data variabel dukungan sosial memiliki nilai signifikan sebesar 0,815 ( $\mathrm{p}>0,05)$, maka skala dinyatakan berdistribusi normal. Variabel kesepian diperoleh nilai signifikan sebesar 0,945 ( $\mathrm{p}>0,05)$ maka skala berdistribusi normal.

\section{Uji Linearitas}

Tabel 4. Uji Linearitas

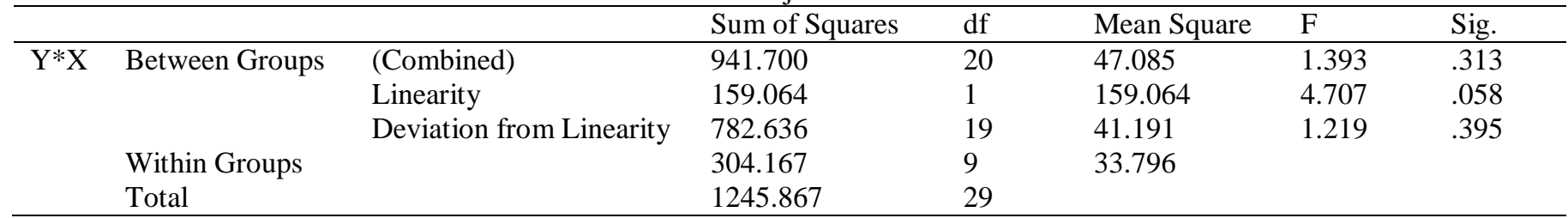

Berdasarkan hasil uji linearitas menunjukkan nilai signifikansi yang diperoleh dari nilai Deviation from Linearity Sig. sebesar 0,395 yang menunjukkan bahwa terdapat hubungan linear secara signifikan antara variabel dukungan sosial dengan kesepian.

\section{Uji Hipotesis}

Tabel 5. Uji Hipotesis

\begin{tabular}{llll}
\hline \multicolumn{2}{l}{ Correlation } & $\mathrm{X}$ & $\mathrm{Y}$ \\
\hline $\mathrm{X}$ & Pearson Correlation & 1 & $-.357^{*}$ \\
& Sig. (1-tailed) & & .026 \\
& $\mathrm{~N}$ & 30 & 30 \\
$\mathrm{Y}$ & Pearson Correlation & $-.357^{*}$ & 1 \\
& Sig. (1-tailed) & .026 & \\
& N & 30 & 30 \\
\hline
\end{tabular}

*. Correlation is significant at the 0.05 level (1-tailed).

Berdasarkan hasil perhitungan uji korelasi Pearson Product Moment menunjukkan bahwa hipotesis yang diuji dalam penelitian ini diterima. Koefisien korelasi uji hipotesis yang diperoleh sebesar $-0,357$ dengan nilai signifikansi 0,026 yang berarti lebih kecil dari 0,05 ( $\mathrm{p}<0,05)$, dapat disimpulkan bahwa ada hubungan yang signifikan dan negatif antara dukungan sosial dengan kesepian pada narapidana dewasa awal lajang.

\section{Pembahasan}

Hasil dari penelitian ini adalah terdapat hubungan negatif antara dukungan sosial dengan kesepian pada narapidana dewasa awal lajang, koefisien korelasi uji hipotesis yang diperoleh sebesar -0,357 dengan nilai signifikansi 0,026. Hal ini mengindikasikan bahwa semakin tinggi dukungan sosial maka semakin rendah tingkat kesepian, begitu pula sebaliknya semakin rendah dukungan sosial maka semakin tinggi kesepian. Hal ini sesuai dengan penelitian yang dilakukan oleh Nur dan Shanti (2011) bahwa ada hubungan negatif yang signifikan antara dukungan sosial keluaga dengan kesepian pada narapidana. Narapidana yang memperoleh dukungan sosial keluarga yang kurang cenderung akan mengalami kesepian, sementara narapidana yang memperoleh dukungan sosial yang cukup merasa tidak kesepian. Hal ini juga menunjukkan akan pentingnya interaksi sosial di kalangan narapidana untuk mengatasi masalah kesepian Fessman dan Lester (dalam Hayati, 2009).

Hasil dari penelitian ini menunjukkan bahwa 11 narapidana memiliki dukungan sosial sangat tinggi (37\%), 16 narapidana memiliki dukungan sosial tinggi $(53 \%), 3$ narapidana yang memiliki dukungan sosial rendah (10\%), dan tidak ada narapidana yang memiliki dukungan sosial sangat rendah (0\%). Rata-rata dukungan sosial yang dimiliki oleh narapidana 65,33 berada pada kategori tinggi (53\%).

Berdasarkan pengamatan yang dilakukan oleh peneliti dapat dilihat bahwa narapidana dewasa awal lajang di rutan memiliki dukungan sosial tinggi, hal ini 
disebabkan karena sebagian besar narapidana dewasa awal yang melajang mampu beradaptasi dengan lingkungan baru dan memiliki hubungan sosial yang yang baik dengan narapidana yang lain. Hal ini juga disebabkan karena narapidana memiliki dukungan sosial yang cukup dari keluarga. Huda (2012) mengatakan bahwa keluarga merupakan dukungan sosioemosional yang bersifat instrumental berupa tindakan, ungkapan rasa cinta, perhatian, simpati dan rasa kebersamaan. Oleh karena itu, meskipun pria atau wanita dewasa awal yang lajang tidak mendapatkan sumber dukungan dari pasangan, mereka masih mendapatkan dukungan dari sumber lain, seperti keluarga dalam hal ini dari orang tua dan saudara kandung. Selain itu, narapidana juga mendapatkan dukungan dari teman-teman di dalam Rumah Tahanan (berdasarkan wawancara dan observasi pada hari Kamis, 3 Oktober 2019).

Raisa dan Ediati (2016) menyebutkan bahwa efek menguntungkan dari dukungan sosial, baik melalui interaksi individu dengan teman dekat yaitu sebagai sumber untuk menghadapi masa-masa yang sulit. Adanya dukungan yang diberikan oleh teman sebaya seperti penerimaan, saling mengerti satu sama lain, dan membuat situasi nyaman menyebabkan dukungan sosial teman sebaya juga dibutuhkan oleh narapidana karena waktu kebersamaan atau bertemu dapat setiap saat. Mereka dapat melakukan aktivitas bersama-sama bahkan berada di kamar yang sama. Sesama narapidana biasanya meminta saran dan juga berbagi cerita atau pengalaman kepada teman sesama narapidana. Hal itu disebabkan karena mereka merasa memiliki perasaan emosional yang sama dalam menghadapi sesuatu. Didukung juga oleh Goetlieb (Smet, 1994) yang menyatakan bahwa teman sebaya merupakan salah satu sumber dukungan sosial yang penting karena teman sebaya dapat memberikan pengertian, penampungan dan dukungan atas masalah-masalah yang dihadapi seseorang.

Hasil penelitian ini juga menunjukkan bahwa 9 narapidana memiliki kesepian sangat rendah (30\%), 18 narapidana memiliki kesepian rendah (60\%), 2 narapidana memiliki kesepian tinggi (7\%), dan 1 narapidana memiliki kesepian sangat tinggi (3\%). Ratarata kesepian yang dimiliki oleh narapidana 26,93 berada pada kategori rendah (60\%).

Berdasarkan pengamatan yang dilakukan oleh peneliti dapat dilihat bahwa faktor yang dapat mempengaruhi narapidana dewasa awal lajang di rutan memiliki kesepian rendah karena narapidana dewasa awal justru merasa kasihan melihat narapidana yang memiliki anak dan isteri saat datang menjenguk, narapidana dewasa awal yang lajang mengatakan bahwa seharusnya mereka bersama-sama membesarkan anaknya dan mencari nafkah untuk keluarga kecilnya (berdasarkan wawancara dan observasi pada hari Kamis, 3 Oktober 2019). Selain itu, pihak rutan juga memberikan pembinaan kepada narapidana melalui ibadah maupun pengajian yang sering dilakukan serta kegiatan Pre-Education (PE) untuk perkenalan dengan warga binaan baru dan juga menjadi wadah untuk pemberitahuan mengenai kegiatan yang akan diselenggarakan di Rumah Tahanan.

Hasil ini berbeda dengan wawancara awal yang telah dilakukan pada bulan Januari 2019 seperti yang dinyatakan pada pernyataan di bawah ini:

"Selama saya berada di sini dan melihat temanteman saya yang dikunjungi oleh pasangan dan juga anak-anaknya membuat saya merasa bahwa di usia saya saat ini seharusnya saya seperti teman-teman saya yang lain yang sudah membangun sebuah keluarga. Sehingga ketika saya mengalami masalah seperti ini saya tidak merasa kesepian karena memiliki keluarga yang dapat mendukung saya dan juga menjadi penyemangat untuk saya".

Perbedaan hasil wawancara awal dan hasil penelitian ini yaitu karena adanya penilaian subjektif, penilaian terhadap gambaran diri tidak selamanya mencerminkan keadaan diri yang sebenarnya, dan terkadang persepsi orang berbeda dengan persepsi individu dalam memandang dirinya. Sears, dkk (dalam Anuari, 2018) menjelaskan bahwa kesepian menunjukkan pada kegelisahan yang subjektif yang dirasakan pada saat hubungan sosial, individu mempersepsikan objek eksternal dan pengalamanpengalaman yang ia rasakan dan kemudian memberi makna terhadap hal-hal itu.

Itryah (2009) mengemukakan bahwa dukungan sosial memberikan pengaruh terhadap kesepian, yang menunjukkan bahwa individu memperoleh kepuasan adalah individu yang banyak mendapat dukungan sosial dari orang-orang yang memiliki hubungan berarti dengan individu misalnya: keluarga.

Dukungan keluarga adalah bantuan yang dapat diberikan kepada anggota keluarga lain baik berupa informasi maupun nasihat yang mampu membuat penerima dukungan akan merasa disayang, dihargai, dan tenteram. Adanya dukungan dari orang tua akan berdampak pada peningkatan rasa percaya diri serta merasa dicintai, bisa berbagi beban, mengekspresikan perasaan secara terbuka dan dapat membantu narapidana dalam menghadapi permasalahan yang sedang terjadi selama menjalani masa hukuman Misgiyanto dan Susilawati (2014).

Besarnya hubungan variabel dukungan sosial terhadap kesepian adalah $12,8 \%$ sedangkan sisanya $87,2 \%$ dipengaruhi oleh variabel lain di luar dukungan sosial. Faktor lain yang dapat mempengaruhi kesepian adalah jenis kelamin Mahargyaningrum (dalam Septiningsih dan Na'imah, 2010) mengemukakan bahwa Laki-laki kurang merasa kesepian dibanding perempuan, dikarenakan laki-laki mampu merealisasikan dirinya 
terhadap lingkungan dengan mudah.

Faktor lain yang mempengaruhi kesepian yaitu tingkat pendidikan dimana hal yang penting dalam menghadapi masalah, semakin tinggi tingkat pendidikan seseorang semakin banyak pengalaman hidup yang dilaluinya, sehingga akan lebih siap dalam menghadapi masalah yang dialami (Berhm, 2002).

Adapun faktor lain yang mempengaruhi kesepian yaitu usia, berdasarkan penelitian Ostrov \& Offer (Berhm, 1992) ditemukan bahwa orang yang paling merasa kesepian justru berasal dari orang-orang yang berusia remaja dan dewasa awal. Suardiman (2011) menyatakan bahwa kesepian akan sangat dirasakan oleh individu yang hidup sendirian, tanpa anak, kondisi kesehatannya rendah, rasa percaya diri rendah, hubungan sosial, kewibawaan dan sebagainya.

\section{SIMPULAN}

Berdasarkan hasil penelitian dan pembahasan yang telah dikemukakan sebelumnya, dapat disimpulkan bahwa ada hubungan negatif antara dukungan social dengan kesepian pada narapidana dewasa awal lajang. Hal ini berarti semakin tinggi dukungan sosial maka semakin rendah kesepian, begitu pula sebaliknya semakin rendah dukungan sosial maka semakin tinggi kesepian yang dialamai.

Peneliti merekomendasikan peneliti selanjutnya dapat mengembangkan faktor-faktor lain yang memengaruhi variabel kesepian pada narapidana seperti jenis kelamin dan status sosial ekonomi. Peneliti selanjutnya dapat melakukan penelitian pada usia yang berbeda (dewasa madya) untuk melihat perbedaan kesepian yang dialami.

\section{DAFTAR PUSTAKA}

Anuari, I. (2018). Hubungan antara kesepian dengan kecanduan internet pada remaja. Surakarta : Universitas Muhammadiyah Surakarta.

Arikunto. (2010). Prosedur Penelitian: Suatu Pendekatan Praktek. Jakarta: Rineka Cipta.

Arumdina, A.F. (2013). Pengaruh Kesepian Terhadap Pemilihan Pasangan Hidup Pada Dewasa Awal Yang Masih Lajang. Jurnal Psikologi Pendidikan dan Perkembangan. 2(3)

Azwar, S. (2013). Metode Penelitian, Yogyakarta: Pustaka Pelajar.

Brehm, S. et al (1992). Intimate Relationship. New York. Mc. Graw Hill.

Bruno,F.J.S. (2000).Conguer Loneliness: Cara Menaklukan Kesepian. Jakarta: PT. Gramedia Pustaka Utama.

Cutrona, C. E., \& Russell, D. W. (1987). The provisions of social relationships and adaptation to stress. Advances in personal relationships, 1(1), 37-67.

Dagun, S.M. (1990). Keluarga Peran Ayah dalam Keluarga.Jakarta: Rineka Cipta
Ekasari, A., \& Susanti, N. (2009). Hubungan antara optimisme dan penyesuaian diri dengan stress pada narapidana kasus napza di lapas Kelas IIA Bulak Kapal Bekasi. Jurnal Soul, 2(2).

Faradhiga, A.Y. (2015). Pengaruh Dukungan Sosial, Loneliness, dan Trait Kepribadian Terhadap Gejala Depresi Narapidana di Lembaga Pemasyarakatan. Skripsi. Jakarta: Fakultas Psikologi Universitas Islam Negeri Syarif Hidayatullah.

Friedman, M. Marilyn. (1998). KeperawatanKeluarga :Teori dan Praktik. Jakarta : EGC.

Gottileb, B.H . 1998. Marshalling Social Support: Formats, Process, and Effect. New York: Sage Publishing.

Gunarsa, S. D. (2004). Dari anak sampai usia lanjut : bunga rampai psikologi anak. BPK Gunung Mulia.

Hasan, A. S. \& Handayani, M. M. (2014). Hubungan antara Dukunga Sosial Teman Sebaya dengan Penyesuaian Diri Siswa Tunarungu di Sekolah Inklusi. Jurnal Psikologi Pendidikan dan Perkembangan. 3(2).

Hayati, S. (2009). Pengaruh Dukungan Sosial terhadap Loneliness pada Lansia. (Skripsi diterbitkan). Medan: Fakultas Psikologi Universitas Sumatra Utara.

Herawati, T., dkk. (2018). Dukungan Sosial, Interaksi Keluarga, dan Kualitas Perkawinan pada Keluarga Suami Istri bekerja. Jur. Ilm. Kel. \& Kons. 11(1) $1-12$.

Huda, N.(2012). Kontribusi Dukungan Sosial Terhadap Kepuasan Hidup, Afek Menyenangkan Dan Afek Tidak Menyenangkan Pada Dewasa Muda Yang Belum Menikah. Skripsi. Fakultas Psikologi Universitas Gunadarma.

Hurlock, E. B. (1994). Psikologi Perkembangan, Suatu Pendekatan Sepanjang Rentang Kehidupan. Jakarta : Erlangga.

Itryah. (2009). Hubungan antara kepercayaan antar pasangan dan lamanya usia perkawinan dengan penyesuaian perkawinan. Journal Psyche, III, 3341.

Meilina, C.P. (2013). Dampak Psikologis Bagi Narapidana Wanita Yang Melakukan Tindak Pidana Pembunuhan Dan Upaya Penanggulangannya. Jurnal Ilmiah. Fakultas Hukum. Universitas Brawijaya. Malang.

Misgiyanto \& Susilawati. D (2014). Hubungan antara Dukungan Sosial Keluarga dengan Tingkat Kecemasan Penderitan Kanker Serviks Paliatif. Jurnal Keperawatan, 5(1).

Nur, A. L., \& Shanti, K. L. P. (2011). Kesepian pada narapidana di lembaga pemasyarakatan Kedungpane Semarang ditinjau dari dukungan 
sosial keluarga dan status perkawinan. Jurnal Psikologi, 4(2), 67-80.

Putri, A. L. D. (2018). Hubungan antara Dukungan Sosial Orangtua dengan Prokrastinasi Akademik pada Mahasiswa Fakultas Psikologi Universitas Kristen Satya Wacana Salatiga. Skripsi. Salatiga: Fakultas Psikologi Universitas Kristen Satya Wacana.

Raisa \& Ediati, A. (2016). Hubungan Antara Dukungan Sosial dengan Resiliensi pada Narapidana di Lembaga Pemasyarakatan Kelas IIA Wanita Semarang. Jurnal Empati. 5(3), 537-542.

Rusell, D.W. (1996). UCLA Loneliness Scale (Version 3): Reliability, Validity, and Factor Structure. Journal of Person Assessment. 66. 20-44.

Santoso, S. (2010). Statistika Parametrik, Konsep dan Aplikasi dengan SPSS. Cetakan Pertama PT Elex Media Komputindo Jakarta: PT Gramedia.

Santrock (2003) John W. Adolescence. Perkembangan Remaja. Edisi Keenam. Jakarta: Erlangga.

Sari, P. I \& Listiyandini, A. R. (2015). Hubungan antara Resiliensi dengan Kesepian (Loneliness) pada Dewasa Muda Lajang. Prosiding PESAT (Psikologi, Ekonomi, Sastra, Arsitektur\&Teknik Sipil). 6.

Septiningsih, S. D \& Na'imah, T. (2010). Kesepian pada Lanjut Usia: Studi tentang Bentuk, Faktor Pencetus dan Strategi Koping. Jurnal Psikologi. 11(2)

Suardiman, S.P. (2011). Psikologi Usia Lanjut. Yogyakarta: Gadjah Mada University Press.

Sugiyono. (2013). Metode Penelitian Kuantitatif, Kualitatif dan $R \& D$. Bandung: Alfabeta $\mathrm{CV}$.

Utami, P. K \& Wijaya, D. Y. (2018). Hubungan Dukungan Sosial Pasangan dengan Konflik Pekerjaan-Keluarga pada Ibu Bekerja. Jurnal Psikologi. 16(1). 